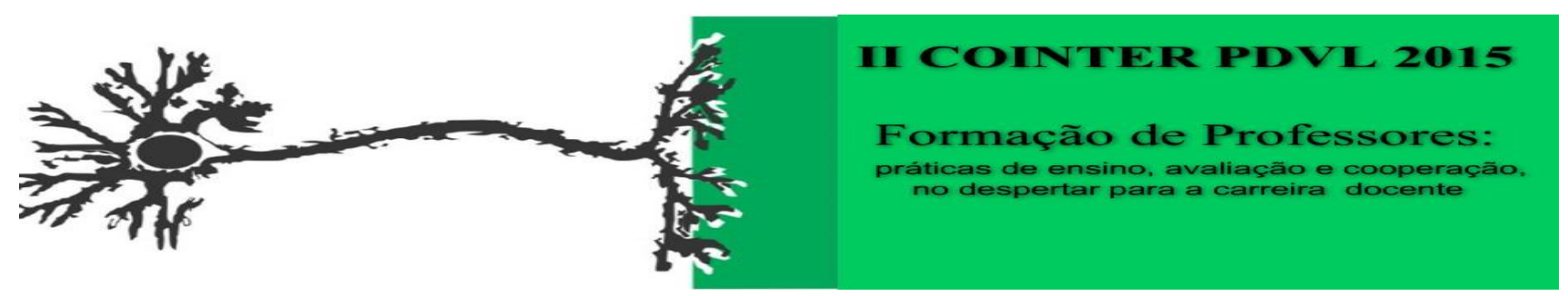

O REVIVER CIÊNCIA: COMO FERRAMENTA DE SOCIALIZAÇÃO DA QUÍMICA ENTRE OS IDOSOS

Apresentação: Relato de Experiência

PONTES, Layce Alicy Cunha Alves ${ }^{1}$; NOGUEIRA, Jonildo Júnior da Silva ${ }^{2}$; ALEXANDRE, Glauris Ferreira $^{3}$; FERREIRA, Jailson Machado ${ }^{4}$

\title{
Introdução
}

A atividade Reviver Ciência é executada pelo Grupo PET Química vinculado ao Programa de Educação Tutorial (PET) e pertencente ao Instituto Federal de Educação, Ciência e Tecnologia da Paraíba (IFPB). A atividade consiste em aproximar a "química do cotidiano" para um público formado por idosos que comumente não tem oportunidade de contato com esta ciência. Expondo experimentos de fácil visualização com explicações adaptadas a realidade, facilitando o processo cognitivo e permitindo a aprendizagem.

As ferramentas audiovisuais são um estímulo para despertar atenção dos idosos, os experimentos químicos que estão associados à cor e a forma dão maior suporte para interação das pessoas com a ciência química. O idoso tem certas limitações no contato com a ciência, o que exige do educador criatividade na abordagem dos temas relacionados à química. Para que haja uma aprendizagem significativa. Por isso, os experimentos químicos têm que ser selecionados com base no nível de dificuldade, priorizando os que estimulam a visão e audição.

\section{Relato de Experiência}

Inicialmente, os integrantes do PET Química executaram uma reunião para identificar as práticas experimentais, tendo como critério a escolha daqueles que envolviam efeitos visuais e sonoros, contextualizando as ações diárias ressaltando a importância do conhecimento cientifico, desmitificando o senso comum do público em questão. De acordo com Paulo Freire (1996, p. 55), "A educação do indivíduo é efetivada quando ele vivencia este processo e o relaciona com o seu

\footnotetext{
${ }^{1}$ Licenciatura em Química, IFPB, alicypontes@hotmail.com

${ }^{2}$ Licenciatura em Química, IFPB, jonildojunior96@gmail.com

${ }^{3}$ Licenciatura em Química, IFPB, glaurisferreira@hotmail.com

${ }^{4}$ Professor Doutor, IFPB, jailsonmf@yahoo.com.br
} 
cotidiano". Durante a realização das práticas há sempre associado a elas uma dinâmica com o auxilio de música com o objetivo de melhorar a interação com o público.

As apresentações são realizadas em locais que possuem grupos da terceira idade, abrigos e asilos. Onde o público demonstrou sempre muito entusiasmo, boa parte ficou surpresa pelo fato do conteúdo estar sempre presente em seu cotidiano, entretanto eles não paravam para observar a ciência fascinante que gira ao seu redor. Os benefícios também repercutiram no âmbito social, mantendo e promovendo a autosuficiência e elevando a autoestima. Os resultados alcançados foram positivos. Houve participação ativa de todos, boa interação com os PETianos e com os demais. Considerando a proposta estabelecida de fortalecer os vínculos interpessoais e proporcionar um momento de lazer e bem-estar físico e mental, pode-se observar que o trabalho mostrou-se como uma forma relevante de propiciar tais benefícios

Após cada apresentação o PET Química se reúniu para avaliar possíveis falhas na execução da apresentação e dinâmica relacionados com a atividade. Posteriormente estes detalhes são aprimorados e reaplicados.

\section{Considerações}

A atividade Reviver Ciência proporcionou aos alunos integrantes do PET uma experiência relevante no processo de formação do profissional da educação. A ação possibilitou aos alunos adaptarem os conteúdos da ciência química para atrair a atenção e estimular o interesse científico dos idosos.

\section{Referências}

FREIRE, P. Pedagogia da autonomia: saberes necessários à prática educativa. São Paulo, Paz e Terra, p. 551996. 